\title{
ANALYSIS OF UNCONTROLLED REACTIVITY INSERTION TRANSIENT OF TRIGA MARK 2000 BANDUNG USING MTR PLATE TYPE FUEL ELEMENT
}

\section{ANALISIS TRANSIEN INSERSI REAKTIVITAS TIDAK TERKENDALI REAKTOR TRIGA MARK 2000 BANDUNG MENGGUNAKAN ELEMEN BAHAN BAKAR TIPE PLAT MTR}

\author{
Surian Pinem, Tukiran Surbakti, Iman Kuntoro \\ Center for Nuclear Reactor Technology and Safety, \\ Indonesian National Nuclear Energy Agency (BATAN) \\ Puspiptek Complex, GD 80, Tangerang Selatan, Banten, Indonesia (15314) \\ E-mail: pinem@batan.go.id
}

Received 4 May 2020, Received in revised form 23 July 2020, Accepted 23 July 2020

\begin{abstract}
ANALYSIS OF UNCONTROLLED REACTIVITY INSERTION TRANSIENT OF TRIGA MARK 2000 BANDUNG USING MTR PLATE TYPE FUEL ELEMENT. In this study, uncontrolled reactivity insertion transient was carried out due to the withdrawal of control rods in nominal power of $1 \mathrm{MW}$ and $2 \mathrm{MW}$. Analysis of reactivity transient was carried out using the WIMSD/5B and MTRDYN codes. The WIMSD/5B code is used to generate cross-sections and the MTRDYN program is used for analysis under transient conditions. Based on calculations on the initial power of $1 \mathrm{MW}$ and $2 \mathrm{MW}$ with the insertion of reactivity of greater than $0.5 \$ / \mathrm{s}$ the reactor operation is not safe because the fuel temperature exceeds the design limit. For reactivity insertion $0.5 \$ / \mathrm{s}$ allows increased power can be stabilized by feedback reactivity. For $1 \mathrm{MW}$ of nominal power, the maximum coolant temperature, cladding and fuel are $86.39^{\circ} \mathrm{C}, 164.86{ }^{\circ} \mathrm{C}$, and $165.33^{\circ} \mathrm{C}$, respectively, whiles for $2 \mathrm{MW}$ of nominal power, the maximum coolant temperature, cladding, and fuel are $89.09{ }^{\circ} \mathrm{C}, 176.96{ }^{\circ} \mathrm{C}$, and $177.602{ }^{\circ} \mathrm{C}$. Based on the calculation results, it is concluded that the feedback mechanism can protect the fuel cladding from a local meltdown if reactivity insertion $0.5 \$ / s$ and the reactor is in nominal power of $1 \mathrm{MW}$ and $2 \mathrm{MW}$.
\end{abstract}

Keywords: reactivity insertion transient, uncontrolled, reactor operation safety, MTRDYN code.

\section{ABSTRAK}

ANALISIS TRANSIEN INSERSI REAKTIVITAS TIDAK TERKENDALI REAKTOR TRIGA MARK 2000 BANDUNG MENGGUNAKAN ELEMEN BAHAN BAKAR TIPE PLAT MTR. Dalam penelitian ini, dilakukan transien insersi reaktivitas tak terkendali akibat penarikan batang kendali dalam daya nominal $1 \mathrm{MW}$ dan $2 \mathrm{MW}$. Analisis transien reaktivitas dilakukan dengan program WIMSD/5B dan MTRDYN. Program WIMSD/5B digunakan untuk mengenerasi tampang lintang dan program MTRDYN digunakan untuk analisis dalam kondisi transient. Berdasarkan perhitungan pada daya nominal $1 \mathrm{MW}$ dan $2 \mathrm{MW}$ dengan insersi reaktivitas lebih dari $0.5 \$ \mathrm{~s}$ reaktor tidak aman karena temperatur bahan bakar melebihi batas desain. Untuk insersi reaktivitas $0.5 \$ / \mathrm{s}$ kenaikan daya dapat distabilkan oleh umpan balik reaktivitas. Untuk daya $1 \mathrm{MW}$, temperatur maksimum pendingin, kelongsong dan bahan bakar masing-masing $86,39{ }^{\circ} \mathrm{C}, 164,86{ }^{\circ} \mathrm{C}$ dan $165,33^{\circ} \mathrm{C}$ sedangkan untuk daya 2 MW masing-masing sebesar 89,09 ${ }^{\circ} \mathrm{C}$, 176,96 ${ }^{\circ} \mathrm{C}$ dan 177,602 ${ }^{\circ} \mathrm{C}$. Berdasarkan hasil perhitungan ini, disimpulkan bahwa mekanisme reaktivitas umpan balik dapat melindungi kelongsong bahan bakar dari pelelehan jika insersi reaktivitas 0,5 \$/s dan reaktor dalam daya nominal $1 \mathrm{MW}$ dan $2 \mathrm{MW}$.

Kata kunci: transien insersi reaktivitas, tak terkendali, keselamatan operasi reactor, program MTRDYN.

\section{INTRODUCTION}

$\mathrm{T}^{\mathrm{T}}$ he National Nuclear Energy Agency of Indonesia (BATAN) has been operating three research reactor units namely the RSG-GAS reactor (30 MW), in Serpong, the TRIGA 2000 reactor (2 MW) in Bandung and the Kartini reactor (100 kW) in Yogyakarta. The TRIGA Mark Bandung reactor has been operated since 1963 and used for research, radioisotope production, and training to improve human resources in the nuclear field. TRIGA MARK 2000 reactor has been increased power twice, first from $250 \mathrm{~kW}$ to $1000 \mathrm{~kW}$, then the second is increased power from 1000 kW to $2000 \mathrm{~kW}$ [1]. To operate the reactor continuously, new fuel elements and control fuel elements are needed [2]. However, there is no fresh fuel element that can be used for the continuation of routine reactor operation. 
Jurnal Iptek Nuklir Ganendra

Ganendra Journal of Nuclear Science and Technology

Vol. 23 No. 2, Juli 2020: 69-76

BATAN proposed to use the $\mathrm{U}_{3} \mathrm{Si}_{2} \mathrm{Al}$ silicide fuel type for the TRIGA MARK 2000 reactor because the fuel is produced domestically by PT INUKI. Therefore, the TRIGA 2000 core calculation has been done using $\mathrm{U}_{3} \mathrm{Si}_{2} \mathrm{Al}$ fuel with a density of $2.96 \mathrm{~g} / \mathrm{cc}$. The design constraint is used for the conversion of TRIGA type rods to plate type fuels. There are no major modifications, such as reactor core shields and reactor systems. The equilibrium core configuration is obtained using 16 fuel elements and 4 control elements [3,4]. Calculation of neutronic, kinetic, and incore fuel management parameters as well as thermodynamic parameters in steady-state conditions have been carried out [5-8]. Based on the calculation results, the conversion core with $2 \mathrm{MW}$ of nominal power requires an additional flow rate in the core [9], but the nominal power of $1 \mathrm{MW}$ can use the current flow rate.

Reactivity insertion accident (RIA) analysis is very important for the safety of reactor operations $[10,11]$. The danger of RIA is that it can damage the integrity of the fuel because the level of fission in the reactor core increases, and it increases the reactor power to an undesired power level. The reactivity insertion accidents (RIA) under controlled and uncontrolled conditions have been investigated by several researchers [12-14]. RIA under control has been carried out to determine the safety of reactor operations [15]. In uncontrolled transients, net reactivity is entirely dependent on external reactivity mechanisms and feedback on reactivity. The contribution of feedback reactivity is the sum of the feedback resulting from changes in fuel temperature (Doppler), changes in the density of coolant (voids), changes in coolant temperature, and feedback caused by thermal expansion of the cladding. The purpose of this study was to determine the power behavior, the fuel temperature of the uncontrolled reactivity insertion transient, and the limit of the insertion of reactivity to prevent melting in the fuel. The safety limit used in this calculation are (1) the maximum fuel temperature must be less than $200^{\circ} \mathrm{C}$ and (2) no coolant boiling occurs on the reactor core.

Calculations are carried out using coupled neutronics, and thermal-hydraulics code MTRDYN [16],17]. The MTRDYN program requires cross-section data on fuel, control rods, and core-forming material under various reactor operating conditions. WIMSD/5B code $[18,19]$ is used for the generation of cell averaged macroscopic and other lattice parameters for overall space-dependent reactor calculations.

\section{METHODOLOGY}

\section{Triga Mark 2000 Reactor Description}

The TRIGA-2000 reactor core conversion will be conducted from fuel rod type to MTR fuel plate type of $\mathrm{U}_{3} \mathrm{Si}_{2}-$ Al with uranium density $2.96 \mathrm{~g} / \mathrm{cc}$ and $<20 \%{ }^{235} \mathrm{U}$ enrichment. The control rod is used the AglnCd-Al material. These fuel elements and control rod type was already used in the RSG-GAS reactor. The schematic diagram of standard fuels and control elements is shown in Figures 1 and 2 respectively. On the $5 \times 5$ core grid positions the TRIGA 2000 consisting of 16 fuels and 4 control rods and surrounded by graphite reflectors and light water moderators. The equilibrium core is divided into 4 burn-up classes where each cycle is designed to replace 4 fuels and 1 control element with the largest fuel burn-up by the fresh fuel and control elements. The core configuration is shown in Figure 3 and the neutronic parameters are shown in Table 1. If the reactor power is $2 \mathrm{MW}$, the minimum flow to the reactor core is $70 \mathrm{~kg} / \mathrm{s}$ [20] and for nominal power of $1 \mathrm{MW}$, the minimum flow rate of $50 \mathrm{~kg} / \mathrm{s}$ is needed.

Table 1. Core parameters of the TRIGA2000 reactor using MTR fuel type [5].

\begin{tabular}{lll}
\hline Core parameters & $\mathbf{2 M W}$ & $\mathbf{1 ~ M W ~}$ \\
\hline Uranium density $\left(\mathrm{g} / \mathrm{cm}^{3}\right)$ & & 2.96 \\
Power $(\mathrm{MWth}) / \mathrm{cycle}$ length (days) & 2.96 & $1 / 240$ \\
Flow rate $(\mathrm{kg} / \mathrm{s})$ & $2 / 120$ & 50 \\
Inlet temperature $\left({ }^{\circ} \mathrm{C}\right)$ & 70 & 40 \\
Pressure $(\mathrm{MPa})$ & 40 & 0.18 \\
Effectively delayed neutron fraction & 0.18 & $7.15 \times 10^{-3}$ \\
Average neutron lifetime $(\mu \mathrm{s})$ & $7.15 \times 10^{-3}$ & 59.83 \\
Fuel temperature coefficient $(\% \Delta \mathrm{k} / \mathrm{k} / \mathrm{K})$ & 59.83 & $-1.91 \times 10^{-3}$ \\
Moderator temperature coefficient $(\% \Delta \mathrm{k} / \mathrm{k} / \mathrm{K})$ & $-1.91 \times 10^{-3}$ & $-8.00 \times 10^{-3}$ \\
Void (water density) reactivity coefficient $(\% \Delta \mathrm{k} / \mathrm{k} / \%$ void) & $-8.00 \times 10^{-3}$ & $-3.86 \times 10^{-3}$ \\
\hline
\end{tabular}




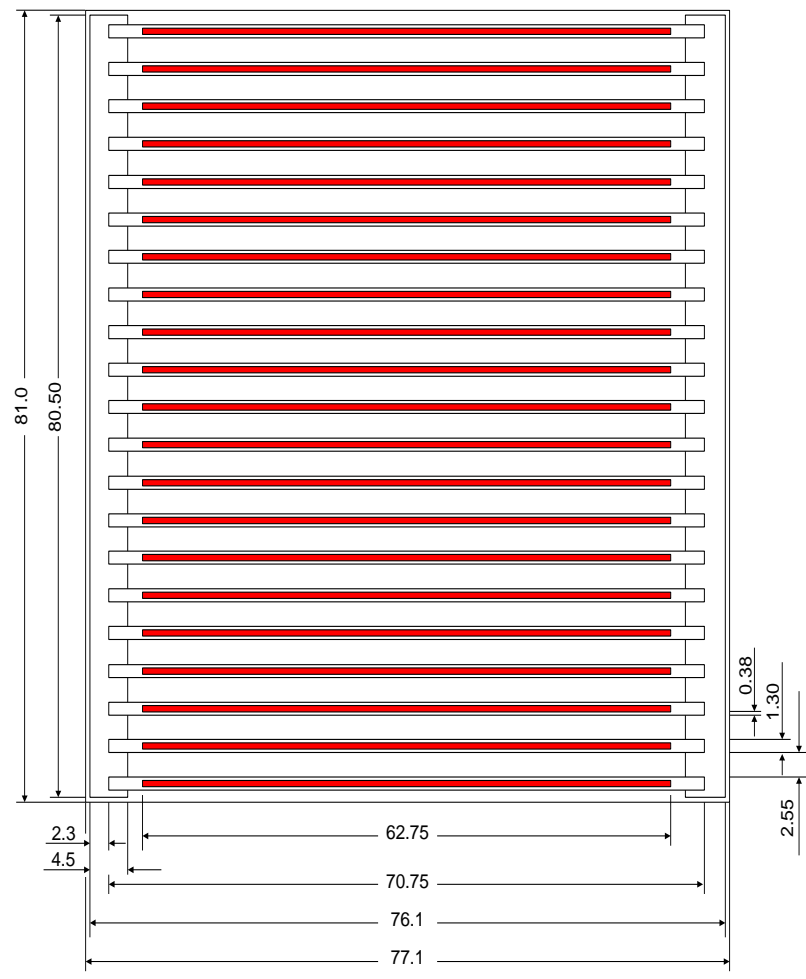

Figure 1. Standard fuel element (unit $\mathrm{mm}$ ) [5].

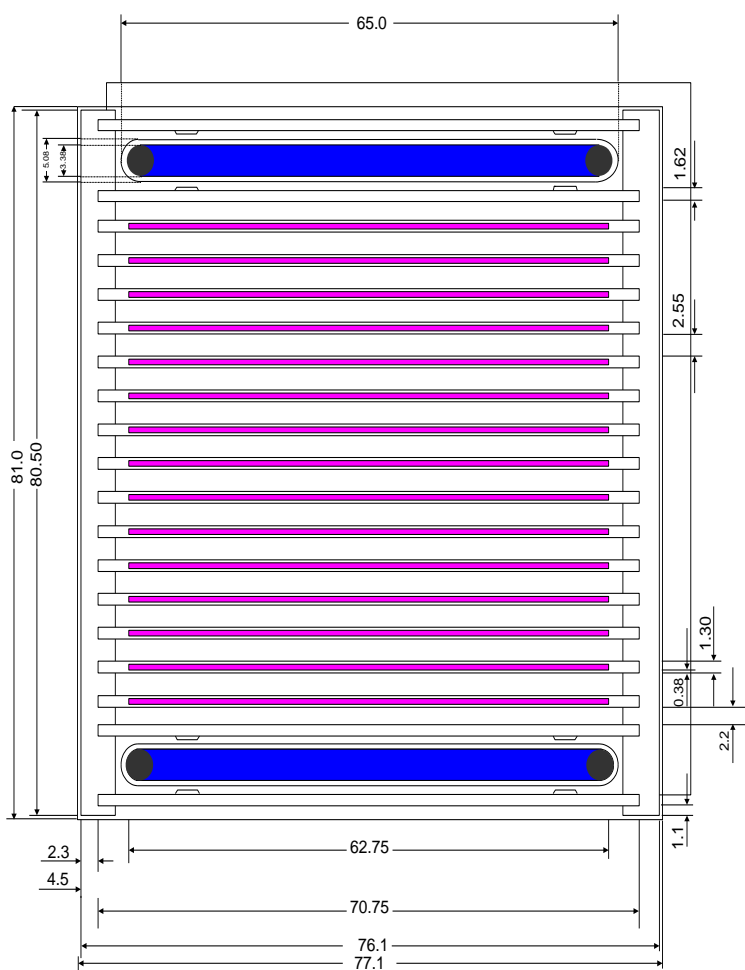

Figure 2. Control fuel element (unit mm) [5].

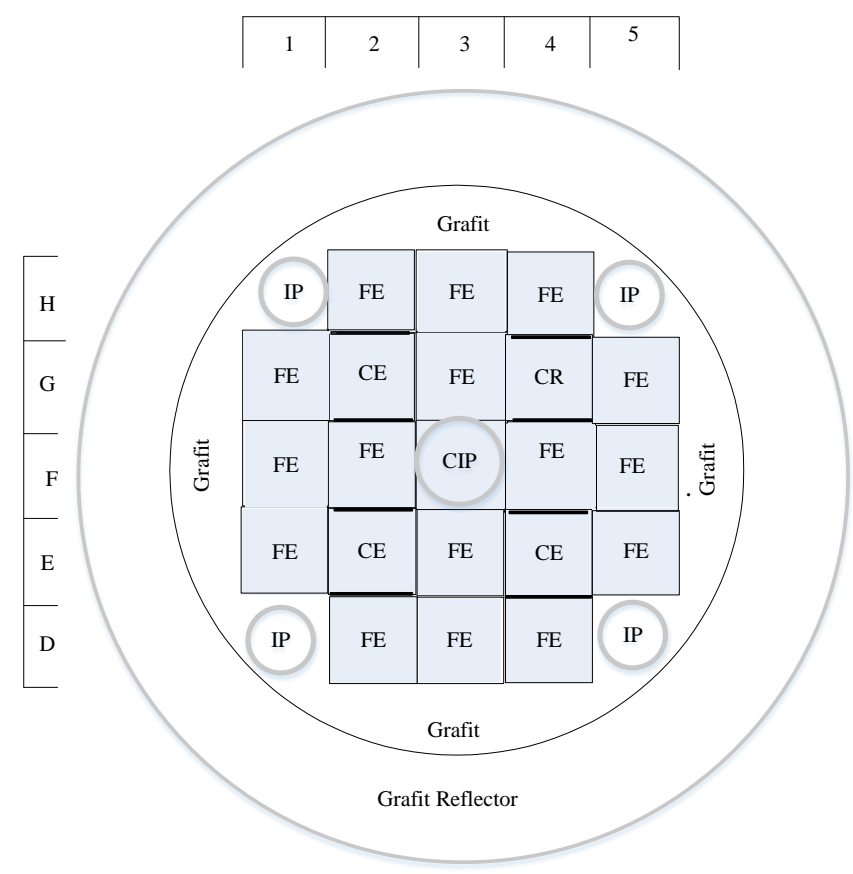

Note $: \mathrm{FE}=$ Fuel Element, $\mathrm{CE}=$ Control Element, IP = Irradiation Position, $\mathrm{CIP}=$ Central Irradiation Position

Figure 3. Equilibrium core with 16 fuel elements and 4 control fuel element [5]. 
Jurnal Iptek Nuklir Ganendra

Ganendra Journal of Nuclear Science and Technology

Vol. 23 No. 2, Juli 2020: 69-76

\section{Cell and Core Calculations}

Calculation of uncontrolled reactivity insertion is performed using the MTRDYN code. The MTRDYN code uses dynamic reactor modeling without simplification, where space and energy variables are maintained. For this reason, external interference such as a control rod is included as a function of location. Likewise, with reactivity feedback (temperature, voids, etc.) handled as a function of location, it means that changes in fuel temperature or moderators at a location in the reactor can have a different feedback effect from other locations. Thermo-hydraulic calculations are also performed as a function of location. The MTRDYN code has been validated using RSG-GAS reactor data where the fuel element is the same as the TRIGA core conversion [17]. The structure of the input and output of the MTR-DYN code is shown in Figure 4. As shown in Figure 4, the input data are core configuration, the magnitude of reactivity insertion, and the cooling flow rate.

The WIMSD/5B code was used for the generating macroscopic cross-section under various reactor operating temperature using ENDF/B.VII.1 library. Derivative constant or reactivity coefficient data are determined by generating a macroscopic cross-section as a function of fuel temperature and moderator $\left(\mathrm{H}_{2} \mathrm{O}\right)$ temperature.

Uncontrolled reactivity transients will occur if the reactor protection system is assumed to fail and the safety of the reactor depends on the feedback reactivity inherent in the reactor. In this calculation, the model used is the same with insertion reactivity under controlled. The reactivity insertion is carried out for various steps to determine the maximum reactivity that can be given without causing the melting of the fuel. For this uncontrolled transient, the behavior of reactor parameters, especially fuel and coolant temperatures for different ranges of reactivity will be analyzed. The analysis was carried out for the nominal reactor power of $1 \mathrm{MW}$ and $2 \mathrm{MW}$ because both of these power are alternatively to be used as core conversion power of TRIGA type fuel to MTR type.

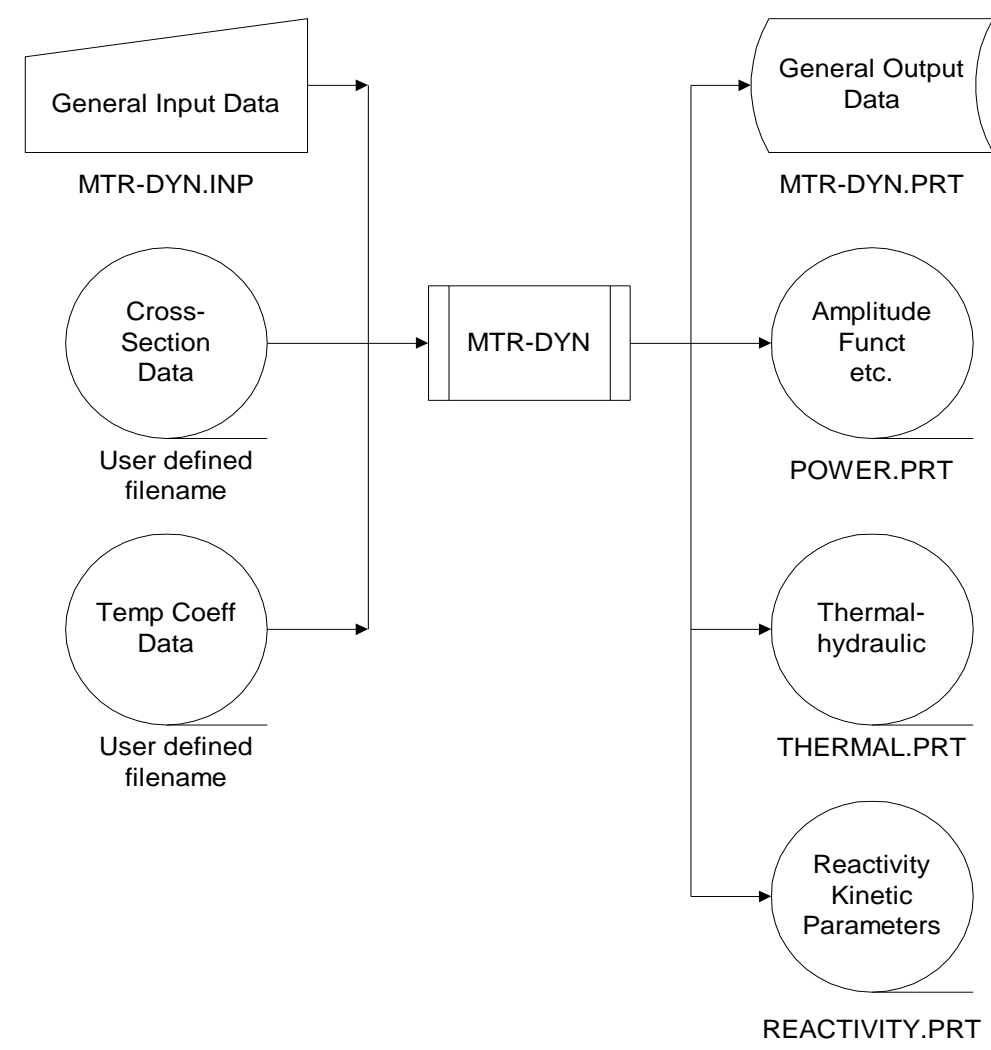

Figure 4. Structure of input/output of the MTRDYN code [17]. 


\section{RESULTS AND DISCUSSION}

The uncontrolled reactivity insertion analysis was performed at a nominal power of $1 \mathrm{MW}$ and $2 \mathrm{MW}$ where the scram system was not available when the reactor exceeded the overpower safety setting. Transient is entirely dependent on the reactivity of the reactor and the mechanism of feedback reactivity. The results of the calculations for the maximum power and temperature of the fuel, cladding, and coolant at a nominal power of $1 \mathrm{MW}$ are shown in Figures 5 - 8. Figure 5 shows the power response as a function of time for insertion of step reactivity $0.5 \$ / \mathrm{s}, 0.6 \$ / \mathrm{s}$ and $0.7 \$ / \mathrm{s}$ at $1 \mathrm{MW}$ nominal power. In Figure 5 , it can be seen that with the reactivity of the reactor above $0.6 \$ / \mathrm{s}$ the reactivity feedback comes from the reactor system being unable to control the reactor. The power increases exponentially from the beginning due to the rapid reactivity of the reactor and the small contribution of the reactivity feedback from the beginning of the transient.

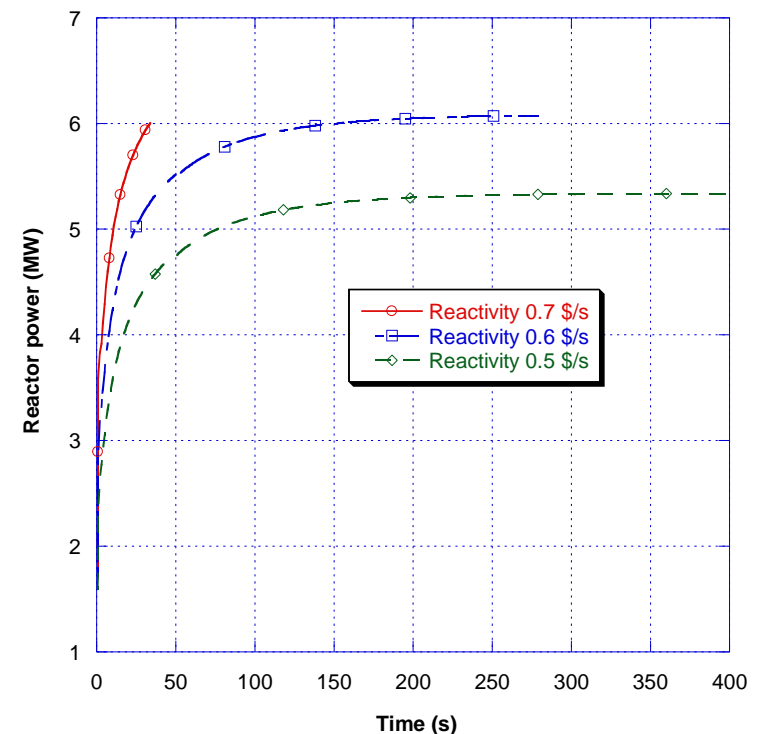

Figure 5. Power response for different step reactivities Insertion \$/s step reactivity.

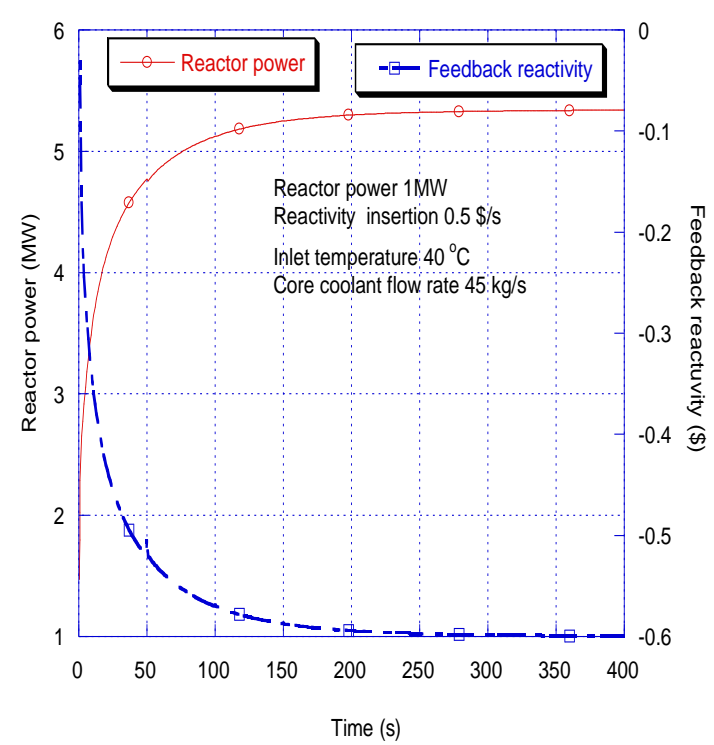

Figure 7. Variation of power with feedback reactivity for $0.5 \$$ s step reactivity.

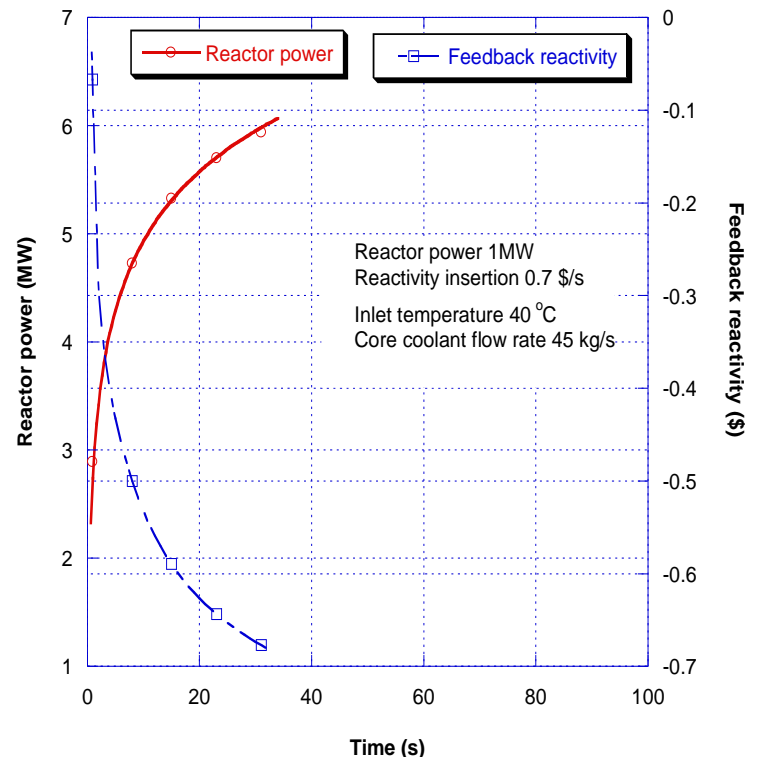

Figure 6. Variation of power with feedback reactivity for $0.7 \$$ s step reactivity.

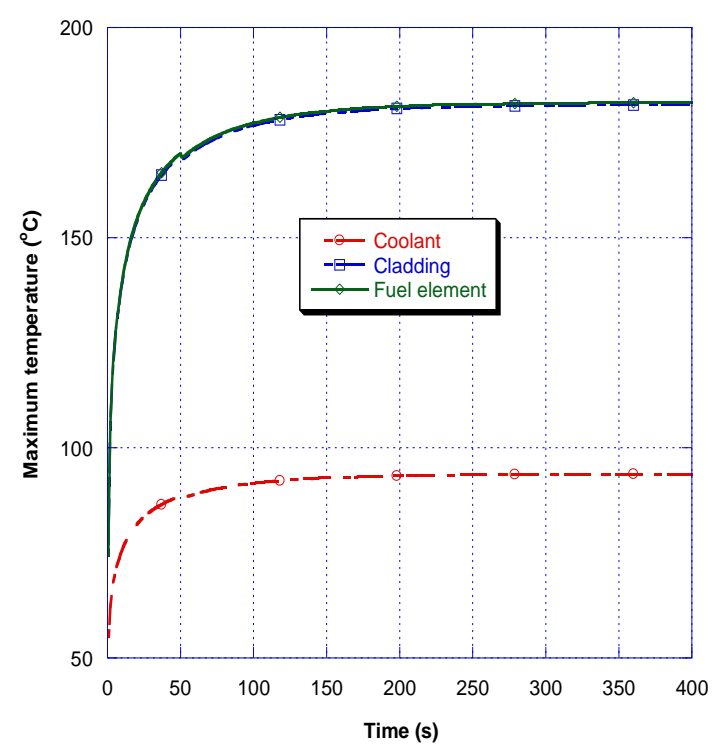

Figure 8. Maximum temperature of with reactivity insertion for $0.5 \$ / s$. 
Jurnal Iptek Nuklir Ganendra

Ganendra Journal of Nuclear Science and Technology

Vol. 23 No. 2, Juli 2020: 69-76

Therefore, for a reactivity greater than $0.6 \$ / \mathrm{s}$, the reactor cannot operate safely because the fuel temperature exceeds the design limit $\left(>200{ }^{\circ} \mathrm{C}\right.$ ) shown in Figure 6 . As shown in Figure 7 for $0.5 \$ / \mathrm{s}$ reactivity insertion, reactor power increase rather rapidly until $4 \mathrm{MW}$ and increase slowly and stabilized at around $5.46 \mathrm{MW}$. The fuel temperature does not instantly increase with the increase in reactor power. The behavior of slow temperature rises under the fast reactor increases due to the negative temperature reactivity coefficients as shown in Figure 7 . The contribution of feedback reactivity brings the fuel temperature back to the steady-state as shown in Figure 8 . Maximum temperatures of coolant, cladding, and fuel are $86.39{ }^{\circ} \mathrm{C}, 164.86{ }^{\circ} \mathrm{C}$, and $165.33^{\circ} \mathrm{C}$, respectively. These results are still below the operating safety limit of the reactor.

The calculations for the maximum power and temperature of the fuel, cladding, and coolant at $2 \mathrm{MW}$ nominal power are shown in Figures $9-12$. In Figure 9 are shown the power response due to the initial reactivity of $0.6 \$ / \mathrm{s}$ and $0.5 \$ / \mathrm{s}$. For a reactivity insertion of $0.6 \$ / \mathrm{s}$ of power increase sharply within $49 \mathrm{~s}$, the reactor power reaches 7.9 MW. This is due to insufficient feedback reactivity to stabilize the reactor as shown in Figure 10. The increased power due to the reactivity of the reactor and the small contribution of reactivity feedback since the beginning of the transient resulted in an increased temperature of the coolant, cladding, and fuel.

For $0.5 \$ / s$ reactivity insertion the reactor power goes up rapidly but can be stabilized by feedback reactivity until it reaches the steady-state. This can be seen in Figure 11 where the power up to $6.43 \mathrm{MW}$ is then stabilized so that there is no increase in coolant, cladding, and fuel temperatures. The feedback reactivity depends on the fuel, cladding, and the coolant density coefficient for the reactor core. The magnitude of the negative reactivity with the external control mechanism or the reactivity feedback generated in the reactor becomes equal to the positive reactivity, thus stabilizing the reactor power. In this case, because the control rod insertion is turned off, only internal feedback loop reactivity will try to control the reactor. It will also determine the effectiveness of the adhesive that is attached to the reactor. The maximum temperature of the coolant, cladding, and fuel at steady state as shown in Figure 12 are $89.09{ }^{\circ} \mathrm{C}, 176.96{ }^{\circ} \mathrm{C}$, and $177.602{ }^{\circ} \mathrm{C}$, respectively. These results are still below the operating safety limit of the reactor.

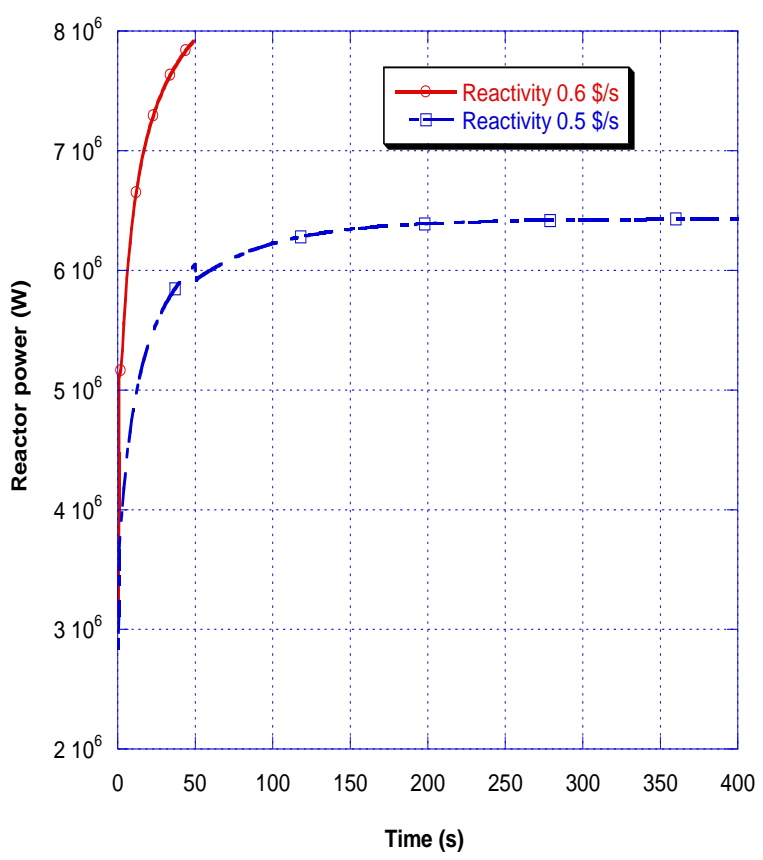

Figure 9. Power response for different step reactivities insertion.

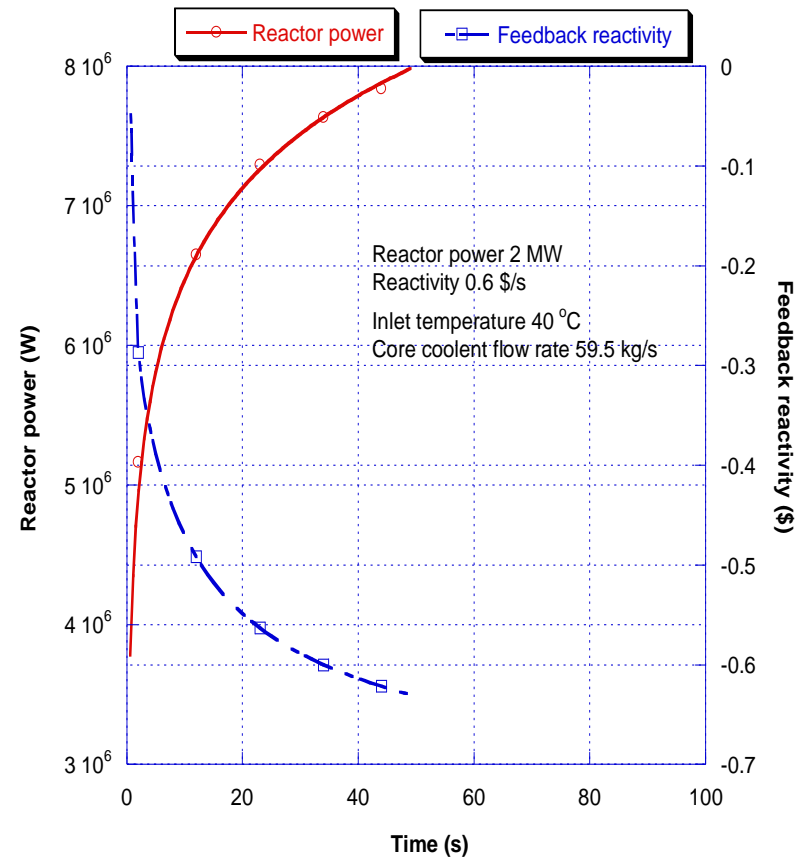

Figure 10. Variation of power with feedback reactivity for $0.6 \$ / s$ step reactivity. 


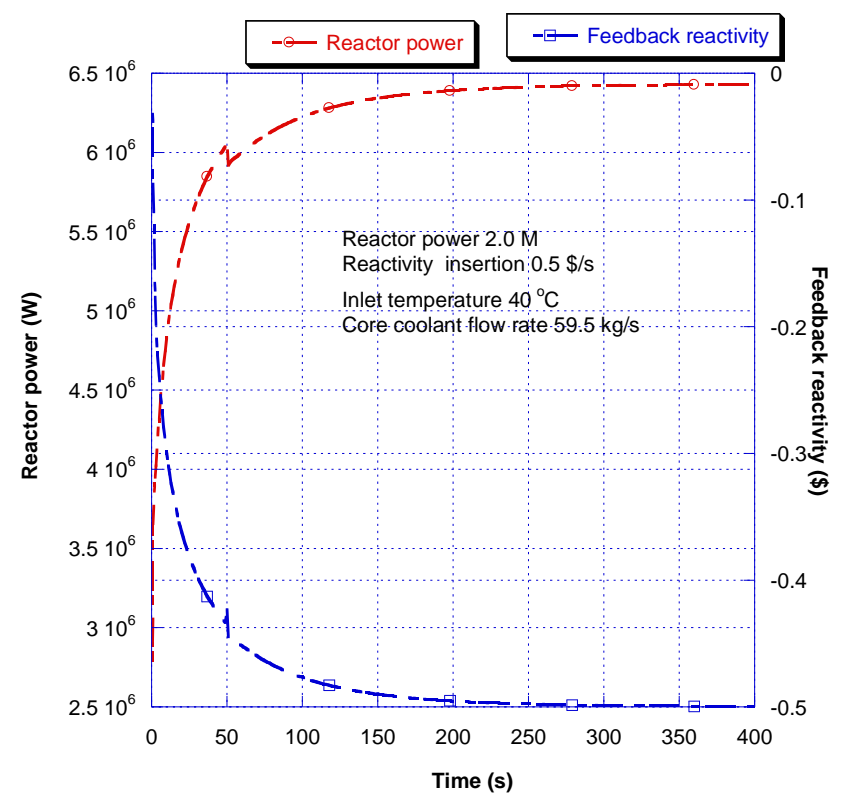

Figure 11. Variation of power with feedback reactivity for $0.5 \$ / \mathrm{s}$ step reactivity.

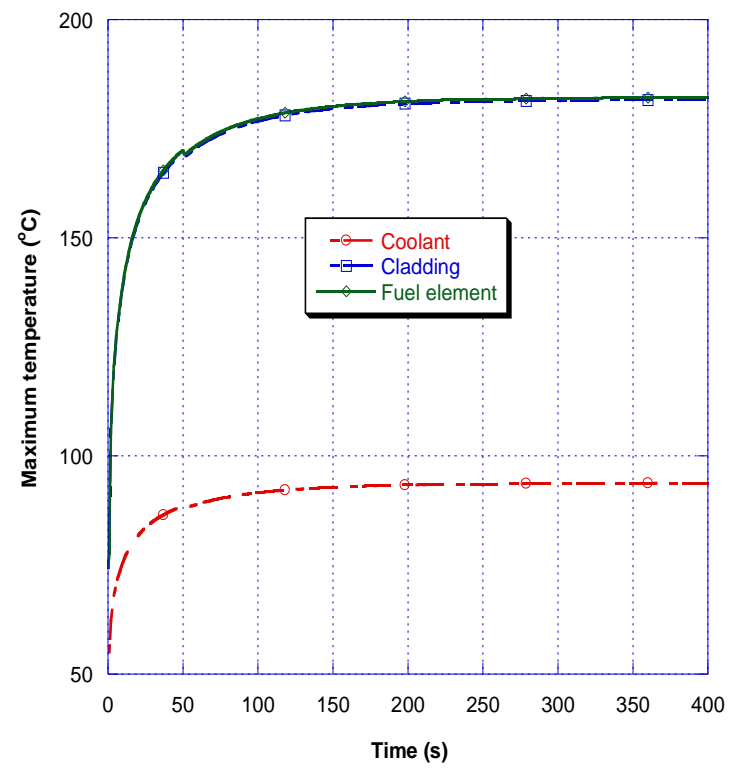

Figure 12. Maximum temperature of with reactivity insertion for $0.5 \$ / \mathrm{s}$.

\section{CONCLUSION}

Analysis of reactivity insertion accident initiated by the uncontrolled withdrawal of a control rod using the MTRDYN code has been carried out. The analyses were carried out for the insertion of reactivity in the range of 0.5 $\$ / \mathrm{s}$ to $0.7 \$ / \mathrm{s}$. The analysis result shows that the maximum insertion of reactivity at a nominal power of $1 \mathrm{MW}$ and 2 $\mathrm{MW}$ is $0.5 \$ / \mathrm{s}$. If the reactivity insertion is greater than $0.5 \$ / \mathrm{s}$, the reactor power cannot be stabilized to a steady state by reactivity feedback. The negative temperature reactivity coefficient and Doppler feedback reactivity, play an important role in bringing the maximum temperature within the design limit. This maximum reactivity insertion value should be considered in the determination of the controlled speed.

\section{ACKNOWLEDGMENT}

This research work was supported by DIPA for the years 2018 and 2019. The authors acknowledge to the Head of PTKRN, PSTNT, and Dr. Syaiful Bakhri as well as the staff of Reactor Physics and Technology Division of PTKRN-BATAN for their cooperation.

\section{REFERENCES}

[1] Z. S. Prasetyo Basuki, Putranto Ilham Yazid, "Desain Neutronika Elemen Bakar Tipe Pelat Pada Teras TRIGA 2000 BANDUNG," Jurnal Sains dan Teknologi Nuklir Indonesia, vol. 15, no. 2, pp. 169-180, 2014.

[2] A. R. Prasetyo Basuki, A.R. Iso Suwarso1, Agus Sunarya, P. Ilham Yazid, Supardjo, "Safety Review of Bandung Triga 2000 Research Reactor Operation Using Control Rod Without Fuel Follower (BKRTTBB)," Jurnal Sains dan Teknologi Nuklir Indonesia Indonesian Journal of Nuclear Science and Technology, vol. 16, no. 2, pp. 93-103, 2015.

[3] A. I. Ramadhan, A. Suwono, E. Umar, and et.al., "Preliminary study for design core of nuclear research reactor of TRIGA Bandung using fuel element plate MTR," Engineering Journal, vol. 21, no. 3, pp. 173-181, 2017.

[4] S. Pinem, T. Surbakti, and T. M. Sembiring, "Core Design TRIGA2000 Bandung Using U3Si2Al Fuel Element MTR Type," Urania Jurnal IImiah Daur Bahan Bakar Nuklir, vol. 24, no. 2, pp. 93-103, 2018.

[5] S. Pinem, T. M. Sembiring, and T. Surbakti, "Core conversion design study of TRIGA mark 2000 bandung using MTR plate type fuel element," International Journal of Nuclear Energy Science and Technology, vol. 12, no. 3, pp. 222-238, 2018. 
[6] E. P. Hastuti, S. Widodo, M. Darwis Isnaini, S. Geni Rina, and B. Syaiful, "Determining Coolant Flow Rate Distribution in the Fuel-Modified TRIGA Plate Reactor," Journal of Physics: Conference Series, vol. 962, no. 1, 2018.

[7] S. Tukiran, P. Surian, and B. Syaiful, "Sensitivity of Reflector on Neutronic Parameter for Conversion Core Design of the TRIGA Research Reactor," Journal of Physics: Conference Series, vol. 1198, no. 2, 2019.

[8] S. Pinem, T. Surbakti, and I. Kuntoro, "Neutronic and Thermal Hydraulics Analysis of Control Rod Effect on the Operation Safety of Triga 2000 Reactor," Urania Jurnal IImiah Daur Bahan Bakar Nuklir, vol. 25, no. 3, pp. 183-192, 2019.

[9] S. Dibyo, K. S. Sudjatmi, Sihana, and et.al., "Simulation of modified TRIGA-2000 with plate-type fuel under LOFA using EUREKA2/RR-code," Atom Indonesia, vol. 44, no. 1, pp. 31-36, 2018.

[10] X. Shen, K. Nakajima, H. Unesaki, and K. Mishima, "Reactivity insertion transient analysis for KUR lowenriched uranium silicide fuel core," Annals of Nuclear Energy, vol. 62, pp. 195-207, 2013.

[11] H. Kazeminejad, "Thermal-hydraulic modeling of reactivity insertion in a research reactor," Annals of Nuclear Energy, vol. 45, pp. 59-67, 2012.

[12] M. H. Altaf, S. M. Tazul Islam, and N. H. Badrun, "RIA analysis of unprotected TRIGA reactor," Atom Indonesia, vol. 43, no. 2, pp. 69-73, 2017.

[13] R. Nasir, M. K. Butt, S. M. Mirza, and N. M. Mirza, "Effect of high density dispersion fuels on transient behavior of MTR type research reactor under multiple reactivity transients," Progress in Nuclear Energy, vol. 85, pp. 511-517, 2015.

[14] R. Nasir, M. K. Butt, S. M. Mirza, and et.al., "Simultaneous multiple reactivity insertions in a typical MTR-type research reactor having U3Si2-Al fuel," Annals of Nuclear Energy, vol. 85, pp. 869-878, 2015.

[15] S. Pinem, T. Surbakti, and P. H. Liem, "Safety Analysis of the TRIGA 2000 U3Si2-Al Fuel Core Under Reactivity Insertion Accidents," Atom Indonesia, vol. 46, no. 1, pp. 33-39, 2020.

[16] T. Surbakti, S. Pinem, and L. Suparlina, "Dynamic Analysis on the Safety Criteria of the Conceptual Core Design in MTR-type Research Reactor," Atom Indonesia, vol. 44, no. 2, pp. 89-97, 2018.

[17] S. Pinem, T. M. Sembiring, and P. H. Liem, "Neutronic and Thermal-Hydraulic Safety Analysis for the Optimization of the Uranium Foil Target in the RSG-GAS Reactor," Atom Indonesia, vol. 42, no. 3, pp. 123128, 2016.

[18] T. M. Sembiring, Tukiran, and S. Pinem, "Nuetronic Desigm of Mxed Oxide-Silicide Cores for the Core Conversionof RSG-GAS Reactor," Atom Indonesia, vol. 27, no. 2, pp. 85-1001, 2001.

[19] WIMSD5, Deterministic Multigroup Reactor Lattice Calculations, NEA-1507/04. 2004.

[20] R. Nazar, K. Sudjatmi, and K. Kamajaya, "the Thermohydraulic Analysis of the Bandung Research Reactor Core With Plate Type Fuel Elements Using the Cfd Code," Jurnal Teknologi Reaktor Nuklir Tri Dasa Mega, vol. 20, no. 3, p. 123, 2018. 